\title{
IQTISHODUNA
}

IQTISHODUNA: Jurnal Ekonomi Islam

E-ISSN: 2443-0056, P-ISSN: 2252-5661

Accredited Number 21/E/KPT/2018

Volume 9 Issue 1, April 2020 | Page: 75-90

DOI: doi.org/10.36835/iqtishoduna.v9i1.472

\section{Shariah Compliance Analysis of Islamic Crowdfunding: Case Study of ethiscrowd.com}

\author{
Ayu Yuningsih ${ }^{1}$, Rifqi Muhammad $^{2}$ \\ ${ }^{1}$ Masters in Economics and Finance ${ }^{2}$ Departement of Accounting, Universitas Islam Indonesia, \\ Jalan Kaliurang No.Km. 14,5 Krawitan Umbulmartani Kec. Ngemplak Kabupaten Sleman \\ Daerah Istimewa Yogyakarta 55584, Indonesia \\ e-mail: ${ }^{1}$ ayuyuningsih92@gmail.com 2rifqimuhammad@uii.ac.id
}

\begin{abstract}
This paper aims to analyze the mechanism and implementation of crowdfunding on ethiscrowd.com and the evaluation of shariah compliance. Based on the parameters of shariah compliance proposed by Rosly (2010) it can be seen that the implementation of shariah crowdfunding of ethiscrowd.com has fulfilled the three parameters of shariah compliance namely 'aqd, maqasid al-shariah and legal documentation. Meanwhile, in the case of financial and accounting reporting disclosed the ethiscrowd.com is not yet not fulfilling existing of regulations, where crowdfunding companies should publish detailed financial reports. The management of ethiscrowd.com only publishes project development reports funded by investors. This is because there is no specific provision for disclosing financial reporting and accounting for financial technology companies, especially those engaged in equity crowdfunding.
\end{abstract}

Keywords: islamic crowdfunding, financial technology, sharia compliance

Abstrak: Paper ini bertujuan untuk menganalisa mekanisme dan implementasi crowdfunding pada ethiscrowd.com serta kesesuaiannya dengan shariah compliance. Berdasarkan parameter kepatuhan syariah yang dikemukakan oleh Rosly (2010) dapat diketahui bahwa implementasi crowdfunding syariah pada ethiscrowd.com telah memenuhi tiga parameter syariah compliance yaitu 'aqd, maqasid al-syariah dan dokumentasi hukum. Sedangkan, dalam hal pelaporan keuangan dan akuntansi yang disampaikan Ethiscrowd.com belum memenuhi ketentuan yang ada, dimana seharusnya perusahaan crowdfunding mempublikasikan laporan posisi keuangannya secara rinci akan tetapi ethiscrowd.com hanya mempublikasikan laporan perkembangan proyek yang didanai oleh investor. Hal ini dikarenakan belum adanya ketentuan khusus yang mengatur tentang pelaporan keuangan dan akuntansi bagi perusahaan financial technology khususnya yang bergerak dibidang equity crowdfunding.

Kata Kunci: Islamic crowdfunding, financial technology, shariah compliance

\section{Introduction}

The crowdfunding industry in Indonesia has grown rapidly in recent years. Crowdfunding is one of the funding alternatives that has developed rapidly in recent years. In Indonesia, the crowdfunding movement began to be discussed since the "Coin for Prita" case in 2009, where the community gathered together to raise funds to help Prita who was hit by a legal case. After that, other crowdfunding movements sprang up which were done not only for charity activities but also by starups who wanted to develop their business. Gulati on Adiansyah mentioned that "Crowdfunding could represent a fundamental transformation in the way 
76 IQTISHODUNA: Jurnal Ekonomi Islam Volume 9 Issue 1, April 2020

startups, micro-enterprise and small and medium-sized enterprise access funding" in other words crowdfunding can represent a fundamental transformation of startup projects, microbusinesses and small and medium businesses in accessing funding. ${ }^{1}$

Crowdfunding is an alternative funding from loans traditional funding. The principle is the same as conventional funding, crowdfunding is open to all individuals or economic actors or groups of people who provide small or large funding via the internet initiated by other people or organizations. $^{2}$

The crowdfunding platform is not only provided by startups that run their businesses conventionally. At present the shariah crowdfunding platform has also begun to emerge. Unlike debt-based crowdfunding, very few companies conduct equitybased crowdfunding. ${ }^{3}$ One company that provides equity-based shariah crowdfunding platforms is ethiscrowd.com.

Ethiscrowd.com is one of the world's first property shariah crowdfunding platforms. The ethiscrowd community consisting of

${ }^{1}$ Adiansah, W., Mulyana, N., \& Fedryansyah, M, "Potensi Crowdfunding Di Indonesia Dalam Praktik Pekerjaan Sosial", Prosiding Penelitian Dan Pengabdian Kepada Masyarakat, No.2 Vol.3 (2016), 155-291.

${ }^{2}$ Sitanggang, M. H. A, "Memahami Mekanisme Crowdfunding dan Motivasi Berpartisipasi dalam Platform Kitabisa.com", E Journal UNDIP, No.3 Vol.23 (2018), 1-11.

${ }^{3}$ Chang, S. E, "Regulation of Crowdfunding in Indonesia", Law Review, No.1, Vol.XVIII (Juli, 2018), 41-71.
25,000 ethical and Islamic crowd investors and donors from 65 countries provided funding for the Social Housing development project in Emerging Indonesia. Every house built helps families get out of poverty. Ethis is headquartered in Singapore, with branches and representative offices in Jakarta, Kuala Lumpur and South Africa. ${ }^{4}$

In running the crowdfunding platform, trust is one of the determinants of success, not a few starups are dim because of their lack of success in convincing investors. In addition, regulatory issues also become an issue that hinders crowdfunding in Indonesia. Unlike conventional, sharia crowdfunding platforms have special provisions related to shariah compliance. Is the implementation of crowdfunding platform in accordance with Islamic principles? Therefore, it is important to further study how the crowdfunding mechanism is and how shariah compliance is or compliancefunding products at ethiscrowd.com. Specifically, this paper aims to analyze the mechanism and implementation of crowdfunding on ethiscrow.com and its compliance with shariah compliance.

\section{Problem}

Shariah compliance can be assessed based on the freedom of an Islamic crowdfunding product from the elements of maysir, usury, gharar

\begin{tabular}{l}
\hline${ }^{4} \begin{array}{c}\text { Ethiscrowd.com, "Project Baban } \\
\text { Bermai", dikutip dari }\end{array}$ \\
Baye \\
https://www.ethiscrowd.com/project/bab \\
an-baye-permai/, pada 2 Juli 2019, pukul \\
12.11 WIB.
\end{tabular}



of Islamic Crowdfunding: Case Study of ethiscrowd.com

and wrongdoing. In addition, the contracts that are applied in crowdfunding must meet the requirements and harmony. ${ }^{5}$ In addition, the assessment of sharia compliance regarding crowdfunding can also be seen through application, legal issues, and solutions to legal problems. ${ }^{6}$ Based on these two studies it can be seen that the sharia compliance assessment benchmarks are only limited to the suitability of the contract used and the documentation used. To assess Shariah compliance in more depth, broader benchmarks are needed, not just limited to the implementation of agreements and legal documentation.

In addition, equity-based crowdfunding has a different mechanism than debt-based crowdfunding or donation-based. This requires more understanding and knowledge of how this equitybased crowdfunding mechanism is implemented.

Thus, the focus of the problem in this study is how is the crowdfunding mechanism and how is the compliance of shariah compliance or crowdfunding product compliance on ethiscrowd.com.

\footnotetext{
${ }^{5}$ Novitarani, A., \& Setyowati, R, "Analisis Crowdfunding Syariah Berdasarkan Prinsip Syariah Compliance Serta Implementasinya Dalam Produk Perbankan Syariah", Al-Manahij, No.2, Vol.XII, (Desember, 2018), 247-262.

${ }^{6}$ Islamiyati, Muthiah Az-Zahra, R., \& Setyowati, R, "Crowdfunding Syariah untuk Pengembangan Produk Perbankan Syariah dari Perspektif Shariah Compliance", Diponegoro Law Journal, No. 21 Vol.6, (2017), 1-16
}

\section{Theoritical review}

3.1 Definition of Crowdfunding

The uniqueness of the crowdfunding concept lies in the fundraising concept that is facilitated by the internet site. ${ }^{7}$ Crowdfunding is not a new idea. This concept emerged around the 100s through the concept of microfinance. The Irish loan fund, initiated by Jonathan Swift, is one of the most prominent examples. The loan funds provide credit to the poor in Ireland, nearly $20 \%$ of Irish households use the loan funds. The concept of crowdfunding arises because of the transformation of the concept of micro finance and the concept of crowdsourcing via the internet (Hobbs, Grigore, \& Molesworth, 2016). Thus crowdfunding is a funding project obtained through the internet. ${ }^{8}$

In a crowdfunding system there is a correlation between investors who have funds and those who have certain business projects that need funds or financial resources. The crowdfunding platform can be integrated practically in every sector of the economy, one of which is the Micro, Small and Medium Enterprises sector. Crowdfunding can also be an alternative financing for startups / SMEs in getting funding. As an internet-based

${ }^{7}$ Mollick, E, "The Dynamics Of Crowdfunding: An Exploratory Study", Journal of Business Venturing, No.1 Vol. 29 (August,2014), 1-16.

${ }^{8}$ Hobbs, J., Grigore, G., \& Molesworth, M, "Success In The Management Of Crowdfunding Projects In The Creative Industries", Internet Research, No.1, Vol.26 (2016), 146-166. 
78 IQTISHODUNA: Jurnal Ekonomi Islam Volume 9 Issue 1, April 2020

financial intermediary platform that collects funds from the general public to finance a project or business unit, crowdfunding informs a project proposal to the general public to raise funds online to realize the project. The crowdfunding framework can be seen in Picture 1 below:

\section{Picture 1. Crowdfunding Framework}

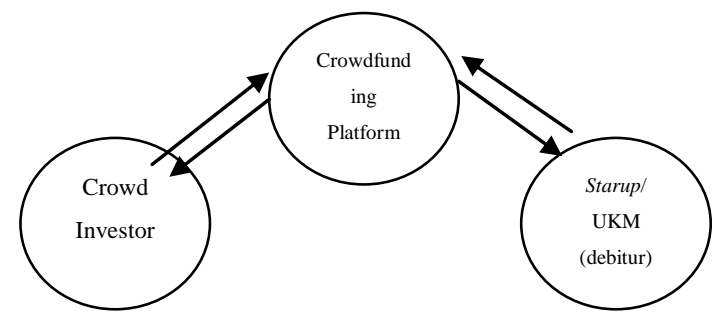

Source: Sitanggang, 2018

Picture 1 explains that in implementing crowdfunding there are three main actors, namely investors, crowdfunding platforms and stratup / UKM. Statups / SMEs that need funds will submit funding requests through the crowdfunding platform. Then the crowdfunding platform will find funding to a group of investors via the internet. Next, the pool of investors will analyze the investment opportunities offered by startups / SMEs through the crowdfunding platform, then if the project proposal is deemed suitable, the pool of investors will provide a commitment to fund the project. Furthermore, fundraising promotion materials until the provision of proper legal documentation for projects offered by startups / SMEs is prepared by the cowdfunding platform. Not only that, the crowdfunding platform also provides services in preparing business plans with financial projections as fundraising materials.

According to S. C \& C. ${ }^{9}$ and Freedman \& Nutting 10 , crowdfunding is divided into 4 types namely as follows:

a. Donation Based

As the name implies, the donors who deposit their capital do not get any reward from the proposed project. Usually crowd-funded donations are intended for non-profit projects such as building orphanages, schools, etc.

b. Reward Based

In this type, those who submit proposals usually offer offers in the form of gifts or other rewards in the form of goods, services or a right, not giving a share of the profits from the project. This type of crowdfunding is usually intended for projects from creative industries such as games, where donors who fund the project will be given interesting features of the games.

c. Debt Based

Actually this type of crowdfunding is the same as an ordinary loan. Prospective borrowers will submit their proposals and donors or creditors will deposit capital deemed as loans with a return in the form of interest.

${ }^{9}$ S. C, H., \& C.H, K, "Effective Matching for P2P Lending by Minning Strong Association Rules", The 3rd International Conference on Industrial an $d$ Bussiness Engineering-ICIBE, (2017), 50.

${ }^{10}$ Freedman, B. D. M., \& Nutting, M. R, "A Brief History of Crowdfunding', Freedman Chicago, No.1, Vol.1 (November, 2015), 10 


\section{d. Equity Based}

The concept is the same as shares, where the money deposited will become equity or part of ownership of the company in return for dividends.

\subsection{Legal Basis of Crowdfunding}

In Indonesia the fund-raising service through an information technologybased stock offering (equity crowdfunding) is regulated in the Financial Services Authority Regulation Number 37 / POJK.04 / 2018 concerning Funding Services through the Equity Crowdfunding Information Technology-Based Stock Offering. Equity Crowdfunding is a stock offering service carried out by the issuer to sell shares directly to investors through an open electronic system network. ( Republic of Indonesia Financial Services Authority, 2018). Financial Services Authority Regulation Number 37 / POJK.04 / 2018 regulates equity crowdfunding in general, both using conventional and sharia systems. Specific rules for issuers offering sharia equity crowdfunding are contained in the Financial Services Authority Regulation Number 37 / POJK.04 / 2018 article 37 which states that the issuer is required to state that the articles of association, activities and types of business, as well as how to manage their business, are based on sharia principles, and has a sharia supervisory board. As such, it is important to ensure that the implementation of Islamic crowdfunding is in accordance with Islamic regulations (Indonesian Financial Services Authority, 2018).

\subsection{Previous Research}

Research related to the analysis of shariah crowdfunding mechanism based on sharia compliance principles has not been done much, as for several related studies including research, ${ }^{11}$ analyzing shariah crowdfunding based on shariah compliance principles and its implementation in shariah banking products suggests that the concept of sharia crowdfunding in shariah banking products implemented in Indonesia basically must be guided by the Qur'an and Sunnah. The suitability of Islamic sharia with the concept of crowdfunding sharia can be seen from the perspective of sharia compliance or shariah compliance which must be free from maysir, usury, gharar and wrongdoing. In addition to that, sharia crwodfunding has at least two types of contracts in the transaction, namely musyarakah and qardh, where the contracts must meet their respective requirements and standards so that the contract can be said to be valid.

Next Islamiyati, Muthiah AzZahra, \& Setyowati research ${ }^{12}$, researching about sharia crowdfunding for the development

\footnotetext{
${ }^{11}$ Novitarani, A., \& Setyowati, R, "Analisis Crowdfunding Syariah Berdasarkan Prinsip Syariah Compliance Serta Implementasinya Dalam Produk Perbankan Syariah", Al-Manahij, No.2, Vol.XII, (Desember, 2018), 247-262.

${ }^{12}$ Islamiyati, Muthiah Az-Zahra, R., \& Setyowati, R, (2017). "Crowdfunding Syariah untuk Pengembangan Produk Perbankan Syariah dari Perspektif Shariah Compliance. Diponegoro Law Journal, N0.21, Vol.6 (2017), 1-16.
} 
80 IQTISHODUNA: Jurnal Ekonomi Islam

Volume 9 Issue 1, April 2020

of shariah banking products from the sharia compiance perspective shows that the implementation of sharia crowdfunding in shariah banking products can be seen from the application, legal issues, and solutions to shariah crowdfunding legal problems.

Based on this research it can be seen that the assessment of Islamic compliance with Islamic financial products is limited to the suitability of the contract and legal problems. While stated that there are four parameters that must be met in assessing the compliance of sharia Islamic financial products, namely 'aqd, maqashid al-Shariah, financial reporting and legal documentation. Thus it is important to ensure the compatibility of sharia crowdfunding products with sharia principles through the assessment of sharia compliance with these products using broader parameters. ${ }^{13}$

\section{Methodology}

This paper uses a qualitative descriptive approach. In analyzing sharia compliance the writer uses sharia parameters developed by Rosly, which states that there are four parameters that must be met in assessing sharia compliance with Islamic financial products, while those parameters can be seen in the figure below ${ }^{14}$ :

Picture 2. Shariah Compliance Parameters

\footnotetext{
${ }^{13}$ Azhar Rosly, S, "Shariah Parameters

Reconsidered", International Journal of Islamic and Middle Eastern Finance and Management,

No.2, Vol.3, (2010), 134.

$$
{ }^{14} \mathrm{Ibid}
$$
}

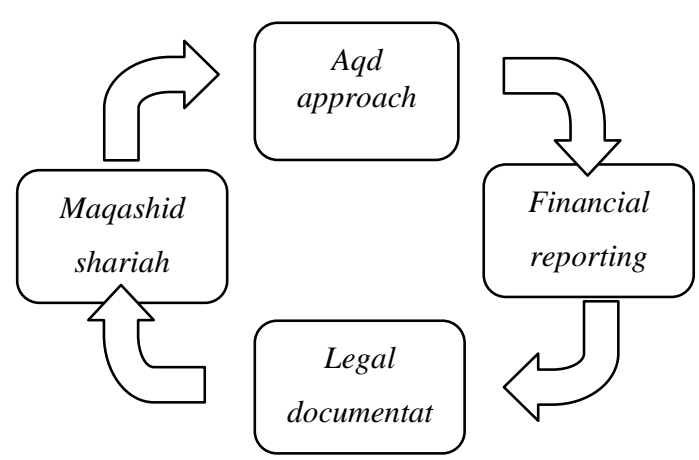

Source: Saiful Azhar Rosly (2010)

Azhar Rosly explained that in general shariah compliance with products offered by shariah banking, takaful, mutual funds and wealth management business is based on 'aqd or contract only while the drive to achieve commercial goals makes Islamic financial institutions adopt conventional instruments and principles in making Islamic financial products. Thus the evaluation of sharia compliance is not enough when viewed from the side of the contract only ${ }^{15}$. Azhar Rosly developed four parameters that can be used in assessing sharia compliance in Islamic financial products, namely by using the covenant approach, financial statement approach, legal documentation approach and the maqasid al syariah approach. ${ }^{16}$ Based on this approach the author tries to assess the compliance of sharia on shariah crowdfunding products available at ethiscrowd.com using the four parameters of shariah compliance. 


\section{Discussion}

5.1 Crowdfunding Mechanism on Ethiscrowd.com

Ethiscrowd.com is the world's first property shariah crowdfunding platform. The ethiscrowd community consists of 25,000 ethical crowd investors from 65 countries who provide funds for social housing development projects in Indonesia. Every house built helps families get out of poverty. Ethis is headquartered in Singapore, with branches and representative offices in Jakarta, Kuala Lumpur and South Africa. Various property investment projects are offered through direct campaigns conducted online on the official website ethiscrowd.com. The contracts used are Wakalah, Istisna and Murabahah. The investment structure at ethiscrowd.com is as follows: ${ }^{17}$

a. Istisna'

The mechanism of the Istisna' contract at ethiscrowd.com can be seen in the image below:

\footnotetext{
${ }^{17}$ Ethiscrowd.com, "Project Baban Baye Permai", quoted from https://www.ethiscrowd.com/project/bab an-baye-permai, on July 2, 2019, time 12.11 p.m.
}

Picture 3. Istisna' Covenant Mechanism

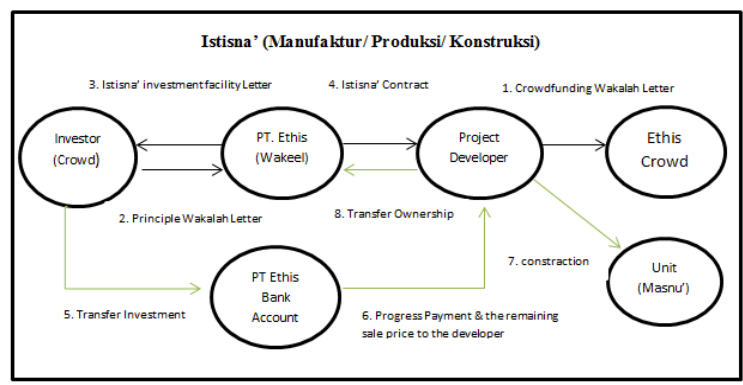

Source: ethiscrowd.com, 2019

Based on picture 3 above, it can be seen that Istisna' covenant between investors and developers is carried out by Wakeel (agent) appointed through Wakalah Letter. The project developer appoints ethiscrowd.com (Singapore) as a crowdfunding agent. Then the investor appoints ethiscrowd.com as wakeel (agent) through Wakalah Letter to carry out a Istisna' covenant with the developer for a certain number of housing units. Next, investors sign a Istisna' facility letter that appoints ethiscrowd.com to carry out the contract on behalf of the investor. Ethiscrowd.com signed an Istisna' covenant 'with the project developer to fund the construction of a number of specified housing units. This agreement is governed by Indonesian law which allows ethiscrowd.com to take legal action in case of any violations by the project developer. Then investors will shift their investment to Singapore dollar-denominated bank accounts ethiscrowd.com in Indonesia. Payments will be made to project developers based on construction milestones. Next, the project developer builds the agreed housing unit. After construction began, the project developer 
82 IQTISHODUNA: Jurnal Ekonomi Islam Volume 9 Issue 1, April 2020

transferred the conditional ownership of the housing unit to Ethiscrowd through a sales certificate (PPJB). After construction is complete, ethiscrowd.com will disburse the remaining selling price to the developer and the Istisna' covenant is completed.

With the completion of Istisna' between ethiscrowd.com and the project developer, the next step is to sell the finished housing unit to the final buyer. This is done through a murabahah covenant.

b. Murabahah

As explained earlier, the murabahah covenant in the crowdfunding project in ethiscrowd.com is carried out after the termination of the istisna contract. Based on Picture 4 above it can be seen that in the implementation of murabahah covenant ethiscrowd.com appoints project developers as agents through Sub-Wakalah Letters, at a cost, to find buyers and sell housing units. Then the project developer will sell the unit to the final buyer approved by Bank Indonesia and the Financing Bank, generally Bank BTN Syariah. After that, ethiscrowd.com transfers the unit sales certificate (PPJB) to the final home buyer through the Standing Instruction in the project developer's bank account, the proceeds from the sale of the housing unit are shared between ethiscrowd and the project developer. Provided that the Bank finances transfers for example $70 \%$ to ethiscrowd.com and 30\% to the Project Developer (as Wakalah fee from ethiscrowd.com). Then ethiscrowd.com transfers the investment amount and profits to investors. The mechanism of murabahah covenant on ethiscrowd.com can be seen in the picture below:

\section{Picture 4.}

\section{Murabahah Covenant Mechanism}

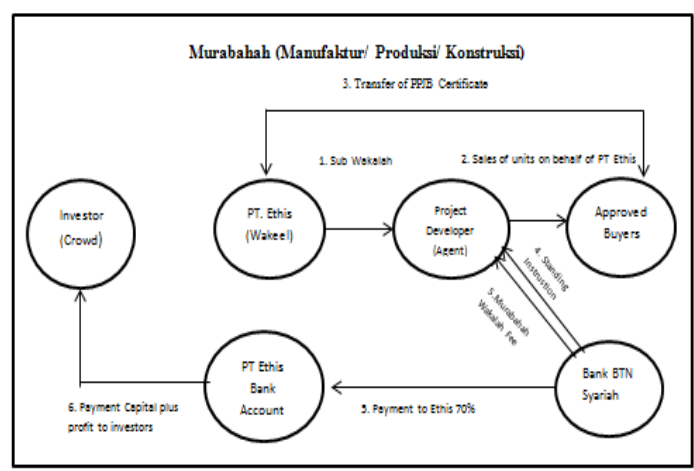

Source: ethiscrowd.com, 2019

c. Flow of Investments

In investing ethiscrowd.com makes it easy for investors. Investors who want to invest simply register themselves on the official website ethiscrowd.com by filling out information and attaching a copy of the ID or verification of investor details. After registering, investors can choose investment projects by exploring the campaigns provided by ethiscrowd.com. after the project is selected the investor sends an investment application to ethiscrowd.com. Furthermore, investors will transfer investment funds online or send them directly to the project bank account in Indonesia. After 

of Islamic Crowdfunding: Case Study of ethiscrowd.com

sending an investment fund, investors are required to send proof of transfer to the address investment@ethiscrowd.com.

After the investment is successful the investor will receive monthly project updates via email and the investor's dashboard. After completing the investor's campaign, the investor will receive his capital back plus realized profits. The simple flow of investing in ethiscrowd.com can be seen in the image below:

\section{Picture 5. Flow of Investments}

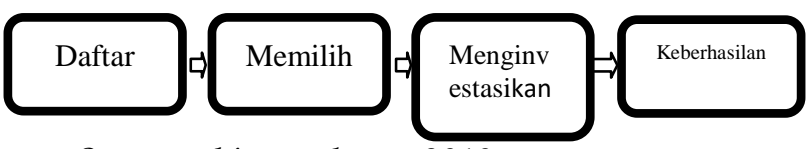

Source: ethiscrowd.com, 2019

\subsection{Analysis of Shariah Compliance Crowdfunding products at Ethiscrowd.com}

\subsubsection{Covenant Approach}

An Islamic financial product must be in accordance with applicable Islamic principles. Muslim scholars tend to harmonize the principles around the contract ('aqd). New products will receive shariah-compliant status when they have fully complied with the existing contractual terms. Therefore, permissibility (halal) and prohibition (haram) in using financial instruments is entirely determined by the legality of the contract $(a q d)^{18}$. In the study of Islamic civil law, the issue of contract occupies a central position because it is the most important way used to obtain a

\footnotetext{
${ }^{18}$ Azhar Rosly, S, "Shariah Parameters Reconsidered", International Journal of Islamic and Middle Eastern Finance and Management, No.2, Vol.3, (2010), 134.
}

purpose or goal, especially with regard to the property or benefits of something legally. In terminology, the contract is defined as a relationship or attachment between consent and qabul in accordance with the will of sharia (Allah and His Messenger) which causes legal consequences on the object of the engagement. ${ }^{19}$

The sentence "in accordance with the will of sharia" in the above definition, the intention is that any agreement made by two or more parties is not considered valid if it is not in line with the will or provisions set by al-shari '(Allah and His Messenger ). If the consent and qabul have been carried out in accordance with its terms and in accordance with the wishes of the Shariah, 'then the legal consequences of the agreement arise. For example, in buying and selling, there is a transfer of ownership of goods from the seller to the buyer and the seller is entitled to receive the price of the goods he sells from the buyer ${ }^{20}$.

Regarding the use of 'aqd, ethiscrowd.com uses Istisna' and murabahah covenant in various property investment projects offered through direct campaigns conducted online on the official website of ethiscrowd.com. In the Financial Services Authority Regulation No. 31 / POJK.05 / 2014 concerning Sharia Financing, Istisna' 'is defined as the sale and purchase of an item by ordering goods in accordance with

\footnotetext{
${ }^{19}$ Sahroni, O, Maqashid Bisnis dan Keuangan Islam, (Jakarta: Raja Grafindo, 2016), 5. ${ }^{20}$ Ibid., p. 6.
} 
84 IQTISHODUNA: Jurnal Ekonomi Islam Volume 9 Issue 1, April 2020

certain criteria and requirements and payment of the price of goods in accordance with an agreement by the parties (Financial Services Authority Republic of Indonesia, 2014). In this case EthisCrowd represented by PT EMI signed an Istisna contract 'with the project developer (PT BDP) to fund the construction of a number of specified housing units. This agreement is governed by Indonesian law which allows EthisCrowd to take legal action in case of any violations by the project developer. Investors diverted their investment into Ethiscrowd's Singapore dollar-denominated bank account in Indonesia. Payments will be made to project developers based on construction milestones. Project developers build agreed upon housing units. After construction began, the project developer transferred the conditional ownership of the housing unit to Ethiscrowd through a sales certificate (PPJB). After construction is complete, Ethiscrowd disburses the remaining selling price to the developer and the Istisna' covenant is completed. With the completion of the Istisna arrangement between Ethiscrowd and the project developer, the next step is to sell the finished housing unit to the final buyer. This is done through a Murabahah covenant.

Based on the explanation above, it can be seen that the application of Istisna' covenant is in accordance with the provisions of the MUI Fatwa DSN Number 06 / DSN-MUI / IV / 2000 Concerning the Sale and Purchase of Istisna' which states that the means of payment must be known in terms of amount and form, whether in the form of money, goods or the benefits. Payments are made according to the agreement. Payment in the form of debt relief. In addition, the application of the Istisna' covenant complies with the provisions of the goods contained in the MUI Fatwa DSN Number 06 / DSN-MUI / IV / 2000 stating that the goods must be clear in their characteristics and can be recognized as debt. The specifications must be explained. Submission was made later. The time and place of delivery of goods must be determined based on agreement. Buyers (mustashni) may not sell goods before receiving them. ${ }^{21}$ This can be seen from the separation between the Istisna' covenant and the Murabahah covenant. Where the murabahah covenant is held after Ethiscrowd and the project Developer complete the Istisna' covenant.

In the Financial Services Authority Regulation Number 31 / POJK.05 / 2014 concerning the Implementation of murabahah Financing is defined as the sale and purchase of an item by confirming its purchase price (acquisition price) to the buyer and the buyer pays it at an excess price (margin) as profit according to the agreement of the parties. The implementation of the murabahah contract on ethiscrowd.com is done through an Islamic Mortgage with the Islamic Bank, where he will buy the house first before selling it to the final

\footnotetext{
${ }^{21} \mathrm{DSN}, \mathrm{MUI}$. "Jual Beli Istishna" No. 06/DSN-MUI/IV/2000, dikutip dari http://dsnmui.or.id., on July, 2019.
} 

of Islamic Crowdfunding: Case Study of ethiscrowd.com

buyer under the government's subsidized housing finance program. Thus PT EMI is paid directly and in full by the Islamic Bank. This is in accordance with the provisions of the murabahah contract object in KHES article 119 which states that the murabahah sale and purchase agreement must be made after the goods in principle become the property of the seller. ${ }^{22}$

Based on the explanation above, it can be concluded that the implementation of the contract on crowdfunding products available at ethiscrowd.com is in accordance with applicable regulations.

\subsubsection{Financial Statement Approach}

Accounting can be defined as the process of identifying, measuring and communicating economic information to enable judgments and decisions based on information by users of information. The purpose of financial statements is to provide information about financial strength, performance and changes in the financial position of a company that is beneficial for many users in making economic decisions. This serves to eliminate obscurity and fraud in financial contracts through factual reporting of transactions that are transacted in business transactions. Financial reporting is a must for all Islamic financial institutions so that stakeholders can measure the true value of society. In financial accounting, the balance sheet or statement of financial position is a summary of the assets or liabilities of a person or organization at a certain date, such as the end of the year. The balance sheet is often described as a portrait of a company's financial condition.

Financial statements are obligations that must be met by crowdfunding platform publishers to stakeholders. This provision is regulated in Financial Services Authority Regulation Number 37 / POJK.04 / 2018 article 39 which states that the issuer is required to submit an annual report to the Financial Services Authority and announce it to the public through the Operator's website and / or the publisher's website no later than 6 (six) month after the publisher's book year ends; in addition to containing information as stipulated in the law regarding limited liability companies, annual reports must contain information about the realization of the use of proceeds from shares offering through the fund collection service; information regarding the realization of the use of funds must be submitted and announced until the funds resulting from the stock offering through the fund collection service have been used up.

In this regard, ethiscrowd.com has not yet presented the financial position report as referred to in the Financial Services Authority Regulation Number 37 / POJK.04 / 2018 article 39. Ethiscrowd.com only presents reports on the development of project funding contained in each project campaign. The information presented in the form of the amount of benefits offered, the amount of funds needed and how far the project progresses. This information 
86 IQTISHODUNA: Jurnal Ekonomi Islam

Volume 9 Issue 1, April 2020

does not contain details about the statement of financial position stipulated in the law of limited liability companies such as a balance sheet, income statement, report on changes in capital. In addition, the information presented by ethiscrowd.com also does not contain information about the realization of the use of funds collected from the project offer until the end of use. Given the importance of the financial position report for stakeholders, ethiscrowd.com should publish its financial position report. Thus, stakeholders, especially investors, can avoid unclearness or fraud in financial contracts through factual reporting of transactions transacted in business transactions ethiscrowd.com.

\subsubsection{Legal Documentation Approach}

Azhar Rosly explain that indirectly, the rights of parties to the contract are defined and made explicit in a contract. The purpose of legal documentation is to provide security and protection for contracting parties where their rights, obligations and responsibilities are clearly spelled out in the terms of the agreement or contract. This security allows them to seek legal protection when the contract is not realized as agreed in the agreement. This means that the clearer the content of the contract is, the stronger the protection for the parties to the contract. ${ }^{23}$

\footnotetext{
${ }^{23}$ Azhar Rosly, S, "Shariah Parameters Reconsidered", International Journal of Islamic and Middle Eastern Finance
}

In this case ethiscrowd.com has clear and detailed legal documents. This can be seen from the complete legal documents presented by ethiscrowd.com for potential investors that can be accessed online. Thus potential investors can analyze the suitability of the contents of the contract before they decide to invest in projects offered by ethiscrowd.com. Provisions regarding this legal documentation are regulated in Financial Services Authority Regulation Number 37 / POJK.04 / 2018 Regarding Fund Arrangement Services through Equity Crowdfunding. Article 35 paragraph (1) states that the issuer must submit documents and / or information to the organizer at least regarding, among other things, the deed of establishment of the company, the amount of funds to be collected in a share offering and the purpose of using funds from the stock offering through the fund collection service, the minimum amount funds obtained through fund collection services, if the issuer determines the minimum amount of funds that must be obtained; the main risks faced by the issuer and the risk of possible illiquidity of shares offered, if there is a risk of the possibility of illiquidity of shares; Issuer's business plan; licensing relating to the business activities of the issuer and / or project to be funded with funds resulting from the offering of shares through the fund collection service; dividend policy. All of these conditions have

and Management, No.2, Vol.3, (2010), 139143. 

of Islamic Crowdfunding: Case Study of ethiscrowd.com

been met by ethiscrowd.com through project proposals offered to investors online. In the project proposal detailed information about the project plan will be funded through crowdfunding. As a sharia-based financial technology company, ethiscrowd.com certainly must have a sharia supervisory board, this is in accordance with the provisions in article 37 which states that in the case of issuers will offer sharia securities in the form of shares through the fund collection service, in addition to documents and / or information as referred in Article 35, the issuer is obliged to state that the articles of association, activities and types of business, as well as ways of managing their business are based on sharia principles and have a sharia supervisory board. This provision has also been fulfilled by ethiscrowd.com as stated in the project proposal offered to investors.

Whereas the agreement documents are regulated in clause 44 which states that the agreement on the administration of funds services between the organizer and the issuer is contained in the deed; the deed referred to may be in the form of a notarial deed; the deed as referred to may be in the form of an Electronic Document; the agreement referred to must contain at least: agreement number; date of agreement; identity of the parties; provisions regarding the rights and obligations of the parties; the period or termination of the agreement; amount of funds to be collected and shares to be offered; minimum amount of funds, if specifying a minimum amount of funds that must be obtained; the amount of commission and fees; provisions regarding fines, if there are provisions regarding fines; dispute resolution mechanism; and the settlement mechanism in the event that the organizer cannot continue its operational activities. The clauses contained in the Istisna 'and murabahah contracts on ethiscrowd.com fulfill the provisions contained in the Financial Services Authority Regulation Number 37 / POJK.04 / 2018 article 44. The contract in detail describes three main parts namely part A explains in detail regarding the project which consists of the type of contract, objectives, time period, investor group, the amount of funds needed, the number of shares offered, the sharia concept used, details of the rate of return, and explains business risks and financial losses. Then part $\mathrm{B}$ of the contract explains in detail the financing details which consist of the amount of financing provided by the investor, general investor information, provisions regarding agency agreements (principle of wakalah): appointment of the company as an investor agent, designation of the developer as a sub-agent of ethhis, an explanation of murabahah sales, purchase price of assets and provisions for disbursement of facilities. Whereas Part $C$ explains in detail the specific terms and conditions for the facilities which comprise expenditure provisions, Istisna agreements', applicable laws, automatic cancellations, representations and guarantees, default events and others. Agreement on the provision of funds service between the 
88 IQTISHODUNA: Jurnal Ekonomi Islam Volume 9 Issue 1, April 2020

organizer and financier is set forth in the form of a standard agreement. In addition, binding the agreement occurs when the investor declares agreement electronically on the contents of the agreement regarding the fund collection service. This indicates that an online transaction agreement or approval agreement is permitted.

In the case of the appointment of ethiscrowd.com as the representative of the investor to manage investor funds in detail, it is regulated in the Financial Services Authority Regulation Number 37 / POJK.04 / 2018 article 45 which states that the agreement on the implementation of fund collection services between the organizer and the investor is set forth in the form of a standard agreement. contains provisions regarding the granting of power of attorney to the organizer to represent the financier as the issuing shareholder, including in the general meeting of the Issuer's shareholders and signing of the deed as well as other related documents.

Based on this explanation, it can be concluded that the legal documentation provisions in the project offered by ethiscrowd.com are in accordance with the applicable provisions.

\subsubsection{The Maqashid al- Syariah Approach}

Sharia principles can be well understood through the aims and objectives of Islamic law (maqashid al-Shariah). This allows Islamic financial institutions to match their products and commercial viability more accurately to the ethical and moral guidance of Islam because of fairness (adl). This is because maqashid al-syariah functions to do two important things, namely the security of benefits and ibqa, namely the eviction of losses or sharia injuries ${ }^{24}$. Maqasid al syariah is used in discussing the concept of Islamic finance because it can be used to set parameters of maslahah and mafsadah; maqasid al syariah makes it possible to understand various levels, sharia objectives, priorities and categories; besides that the strong relationship between maqasid al syariah, fiqh rules and Islamic jurisprudence rules makes maqasid al-sharia a macro discipline that connects with other disciplines in the field of Islamic science. ${ }^{25}$

One of the goals of sharia is the preservation and protection of the basic needs (daruriyat) of humans without which life will be filled with anarchy and chaos. The dharuriyat covers more than five objectives, namely: (1) preserving religion (hifzh al-din); (2) guarding the soul (hifzh alnafs); (3) guarding reason (hifzh al'aql); (4) guarding offspring (hifzh alnasl); (5) safeguarding property (hifzh al-mal) ${ }^{26}$.

Maqasid has an important role in developing Islamic economics and finance. The importance of this role refers to the objectives of sharia in finance, business transactions and the overall objectives of sharia for

\footnotetext{
${ }^{24}$ Ibid., p.136-137.

${ }^{25}$ Putra, M. D, "Maqasid Al Shari'ah Dalam Keuangan Islam (Tinjauan Teoritis atas Pemikiran Dr Ahcene Lahsasna)", Iltizam Journal of Shariah Economic Research, No.1, Vol.1, (2017), 61-77.

${ }^{26}$ Ibid.
} 
wealth, as mentioned in the concept of maqasid, preservation and protection of wealth is one of the objectives of sharia, classified in the daruriyyat category. ${ }^{27}$

Maqasid Syariah in crowdfunding is important to bring transparency and honesty in the crowdfunding platform. This is aimed at avoiding gharar and ambiguity, misleading and wrong presentation and to enable investors to make the right decision. Therefore, to achieve this goal ethiscrwod.com explains in detail about the products offered to investors through proposals that are campaigned online. In addition, the contract is made in detail to protect the parties to the contract. This is intended to protect assets (hifzh almal) owned by investors. Thus, ethiscrowd.com has fulfilled the maqashid syariah parameters.

\section{Closing}

Based on shariah compliance parameters, it can be seen that the implementation of sharia crowdfunding on ethiscrowd.com has fulfilled three shariah compliance parameters, namely 'aqd, maqasid al-syariah and legal documentation. Meanwhile, in terms of financial reporting and accounting, ethiscrowd.com has not fulfilled the existing provisions, which should be as an Islamic financial institution, ethiscrowd.com publishes a statement of its financial position. Thus, stakeholders, especially investors, can avoid unclearness or fraud in financial contracts through factual reporting of transactions transacted in business transactions ethiscrowd.com.

Islamic Crowdfunding is a relatively new thing in an investment fund collection system. In examining this matter, the writer faces limitations on data and information. The lack of research conducted, the absence of specific rules governing Islamic crowdfunding and the lack of Islamic financial technology institutions that provide crowdfunding platforms are obstacles faced by the author in conducting this research.

Based on the results of this study, some recommendations include regulators expected to be able to make specific policies or rules related to Islamic financial technology. As for sharia fintek practitioners, they should pay more attention to sharia compliance, especially in terms of financial reporting. In addition, investors are expected to be more careful and selective in investing in the platform platform. Because the ease of investing does not mean risk free. Meanwhile, further research is expected to carry out further research related to sharia compliance in sharia crowdfunding using broader parameters and more data.

\section{REFERENCES}

Adiansah, W., Mulyana, N., \& Fedryansyah, M. 2016. Potensi Crowdfunding Di Indonesia Dalam Praktik Pekerjaan Sosial. Prosiding Penelitian Dan Pengabdian Kepada Masyarakat, $3(2)$. https://doi.org/10.24198/jppm.v3i $\underline{2.13655}$

\section{${ }^{27}$ Ibid}


90 IQTISHODUNA: Jurnal Ekonomi Islam Volume 9 Issue 1, April 2020

Azhar Rosly, S. 2010. Shariah parameters reconsidered. International Journal of Islamic and Middle Eastern Finance and Management, 3(2), 132-146. https://doi.org/10.1108/17538391 011054372

Chang, S. E. 2018. Regulation of Crowdfunding in Indonesia. Law Review, XVIII(Juli), 41-71. https://doi.org/10.2139/ssrn.3122 $\underline{987}$

DSN, D. S. N. 2000. Jual Beli Istishna'. , Pub. L. No. 06/DSNMUI/IV/2000, 1

DSN, D. S. N. 2000. Murabahah. , Pub. L. No. 04/DSN-MUI/IV/2000

ethiscrowd.com. 2019. Project Baban Baye Permai. Retrieved from https://www.ethiscrowd.com/pro ject/baban-baye-permai

Freedman, B. D. M., \& Nutting, M. R. 2015. A Brief History of Crowdfunding. Freedman Chicago, 1(1), 10. https://doi.org/10.1016/j.cell.2015 .03 .044

Hobbs, J., Grigore, G., \& Molesworth, M. 2016. Success in the management of crowdfunding projects in the creative industries. Internet Research, 26(1), 146-166. https://doi.org/10.1108/IntR-082014-0202

Islamiyati, Muthiah Az-Zahra, R., \& Setyowati, R. 2017. Crowdfunding Syariah untuk Pengembangan Produk Perbankan Syariah dari Perspektif Shariah Compliance. Diponegoro Law Journal, 6(21), 1-16.

Mollick, E. 2014. The dynamics of crowdfunding: An exploratory study. Journal of Business Venturing, 29(1), 1-16. https://doi.org/10.1016/j.jbusvent .2013 .06 .005

Novitarani, A., \& Setyowati, R. 2018.
Analisis Crowdfunding Syariah Berdasarkan Prinsip Syariah Compliance Serta Implementasinya Dalam Produk Perbankan Syariah. Al-Manahij, XII, 247-262. https://doi.org/10.1017/CBO9781 107415324.004

Otoritas Jasa Keuangan republik Indonesia. 2014. Peraturan Otoritas Jasa Keuangan Nomor 31/POJK.05/2014 Tentang Penyelenggaraan Usaha Pembiayaan Syariah. Peraturan Otoritas Jasa Keuangan, 27-38. Retrieved from http://www.ojk.go.id/

Otoritas Jasa Keuangan republik Indonesia. 2018. Peraturab Otoritas Jasa Keuangan Republik Indonesia Nomor 37/POJK.04/2018. Tentang Layanan Urun Dana Melalui Penawaran Saham Berbasis Teknologi Informasi (Equity Crowdfunding). Peraturan Otoritas Jasa Keuangan, 1-74.

Putra, M. D. 2017. Maqasid Al Shari'ah Dalam Keuangan Islam (Tinjauan Teoritis atas Pemikiran Dr Ahcene Lahsasna). Iltizam Journal of Shariah Economic Research, 1(1), 61-77.

S. C, H., \& C.H, K. 2017. Effective Matching for P2P Lending by Minning Strong Association Rules. The 3rd International Conference on Industrial and Bussiness EngineeringICIBE, 30-33. New York.

Sahroni, O. 2016. Maqashid Bisnis dan Keuangan Islam. Jakarta: Raja Grafindo.

Sitanggang, M. H. A. 2018. Memahami Mekanisme Crowdfunding dan Motivasi Berpartisipasi dalam Platform Kitabisa.com. E Journal UNDIP, 23(3), 1-11. Retrieved from https://ejournal3.undip.ac.id/inde x.php/interaksionline/article/view/20859/19553 